\title{
Cutaneous manifestations in a patient with adult-onset Still's disease
}

\section{Objawy dermatologiczne u dorosłego pacjenta z chorobą Stilla}

\author{
Hubert Aleksandrowicz, Marta Kasprowicz-Furmańczyk, Agnieszka Owczarczyk-Saczonek, Waldemar J. Placek \\ Department of Dermatology, Sexually Transmitted Diseases and Clinical Immunology, Olsztyn, Poland \\ Katedra i Klinika Dermatologii, Chorób Przenoszonych Drogą Płciową i Immunologii Klinicznej, Olsztyn, Polska \\ Dermatol Rev/Przegl Dermatol 202।, 108, 145-152 \\ DOI: https://doi.org/l0.5। |4/dr.2021. 107286
}

\section{CORRESPONDING AUTHOR/ ADRES DO KORESPONDENCJI:} lek. Hubert Aleksandrowicz Katedra i Klinika Dermatologii, Chorób Przenoszonych Drogą Płciową

i Immunologii Klinicznej Olsztyn tel.: +48 896786670 e-mail: hubert.aleksandrowicz@ gmail.com

\begin{abstract}
Introduction. Adult-onset Still's disease is a systemic inflammatory disease characterized by fever, arthritis, lymphadenopathy, splenomegaly, inflammation of internal organs, and skin lesions.

Objective. Presentation of a rare, systemic inflammatory disease associated with cutaneous manifestations.

Case report. A 52-year-old woman was admitted to the Department of Dermatology with erythematous skin lesions associated with with intermittent itch. For a year before hospital admission, the skin lesions recurrently appeared in the late afternoon and resolved completely at night.

Conclusions. The cutaneous lesions in adult-onset Still's disease have a tendency tends to develop and disappear in episodes associated with fever. The typical cutaneous manifestations include erythematous or erythematopapular lesions, usually with a salmon-like tint. However, the disease may also be associated with an atypical cutaneous presentation, which should be taken into consideration to ensure early diagnosis and effective treatment to prevent joint damage.
\end{abstract}

\section{STRESZCZENIE}

Wprowadzenie. Choroba Stilla u dorosłych jest układową chorobą zapalną cechującą się gorączką, zapaleniem stawów, powiększeniem węzłów chłonnych i śledziony, stanami zapalnymi narządów wewnętrznych oraz zmianami skórnymi.

Cel pracy. Przedstawienie przypadku choroby Stilla, rzadkiej układowej choroby zapalnej przebiegającej z objawami skórnymi.

Opis przypadku. Kobieta 52-letnia została przyjęta do Kliniki Dermatologii w celu diagnostyki zmian rumieniowych z okresowo występującym świądem. Od roku, przed przyjęciem do Kliniki, zmiany skórne pojawiały się w późnych godzinach popołudniowych i ustępowały całkowicie w nocy.

Wnioski. Osutka w przebiegu choroby Stilla u dorosłych występuje u około 90\% pacjentów. Pojawia się i ustępuje wraz z występującą epizodycznie gorączką. Typowe zmiany skórne mają postać plam rumieniowych lub zmian rumieniowo-grudkowych o charakterystycznym, łososiowym zabarwieniu. W przebiegu choroby Stilla mogą również wystąpić nietypowe objawy skórne, co utrudnia postawienie właściwej 
diagnozy i rozpoczęcie skutecznego leczenia zapobiegającego destrukcji stawów.

Key words: adult-onset Still's disease, skin rash, salmon-colored skin lesions.

Słowa kluczowe: choroba Stilla u dorosłych, osutka, zabarwienie łososiowe.

\section{INTRODUCTION}

Adult-onset Still's disease (AOSD) is a rare systemic inflammatory disease which is characterized by fever, arthritis, inflammation of internal organs, lymphadenopathy, splenomegaly, and skin rash [1] The origin is unknown, and there is no sex predilection for developing the disease [1, 2]. Various factors have been implicated in the etiology of the disorder, including the rubella and mumps viruses or the Epstein-Barr virus $[1,3,4]$.

A characteristic feature of the disease is hectic fever which does not respond to antibiotic treatment. The condition may affect several joints at the same time. Another AOSD-specific symptom is isolated bony ankylosis caused by bony fusion of the carpal bones. Other manifestations include epigastric pain, hepatomegaly or splenomegaly, myalgia exacerbated by fever, pharyngitis and lymphadenopathy (mainly in the neck region) $[1,3,5,6]$.

\section{CASE REPORT}

In October 2018, a 52-year-old woman was admitted to the Dermatology Department to undergo diagnostic work-up for erythematous skin lesions with intermittent itching. In February 2015, she was hospitalized in the Rheumatology Department with painful joints in the hands and feet, accompanied by fever up to $40^{\circ} \mathrm{C}$. Before the onset of fever, a maculopapular skin rash appeared, initially on the upper extremities and then spreading all over the body, accompanied by painful wrist and ankle joints. Still's disease was diagnosed, and treatment was started with prednisone $20 \mathrm{mg} /$ day. After a year, methotrexate at a dose of $15 \mathrm{mg} /$ week was added, and the prednisone dose was reduced to $5 \mathrm{mg}$ / day. During this treatment, the patient was admitted to the Dermatology Department.

Physical examination performed on admission revealed erythematous and edematous lesions on the skin of the upper extremities, trunk, and thighs (figs. 1, 2). The patient's history showed that for a year before hospital admission, skin lesions had appeared in the after-

\section{WPROWADZENIE}

Choroba Stilla u dorosłych (adult-onset Still's diseases - AOSD) jest rzadką, układową chorobą zapalną cechującą się gorączką, zapaleniem stawów, stanami zapalnymi narządów wewnętrznych, powiększeniem węzłów chłonnych oraz osutką [1]. Przyczyna AOSD jest nieznana, a częstość jej występowania jednakowa u obu płci [1, 2]. W etiologii choroby podejrzewa się udział różnych wirusów, takich jak wirus różyczki, świnki i Epsteina-Barr [1, 3, 4].

Charakterystyczna jest gorączka o charakterze hektycznym, która nie reaguje na leczenie antybiotykami. Choroba może zajmować jednocześnie kilka stawów. Typowe dla AOSD jest również występowanie tzw. izolowanego bloku kostnego, powstałego w wyniku zrośnięcia kości nadgarstka. Do dodatkowych objawów należą: dolegliwości bólowe w nadbrzuszu, powiększenie śledziony lub wątroby, dolegliwości bólowe mięśni nasilające się wraz z gorączką, zapalenie gardła oraz powiększenie węzłów chłonnych, głównie na szyi $[1,3,5,6]$.

\section{OPIS PRZYPADKU}

W październiku 2018 roku 52-letnia kobieta została przyjęta do Kliniki Dermatologii w celu diagnostyki zmian rumieniowych z okresowo występującym świądem. W lutym 2015 roku była hospitalizowana na oddziale reumatologii z powodu dolegliwości bólowych stawów rąk i stóp z towarzyszącą gorączką do $40^{\circ} \mathrm{C}$. Przed wystąpieniem gorączki pojawiła się osutka plamisto-grudkowa, początkowo na kończynach górnych, później na całej skórze, której towarzyszyły bóle stawów nadgarstkowych i skokowych. Rozpoznano chorobę Stilla i zalecono leczenie prednizonem w dawce $20 \mathrm{mg} /$ dobę, po roku dołączono metotreksat w dawce $15 \mathrm{mg}$ /tydzień oraz zmniejszono dawkę prednizonu do $5 \mathrm{mg} /$ dobę. Tak leczona pacjentka trafiła do Kliniki Dermatologii.

W badaniu podmiotowym przy przyjęciu występowały zmiany rumieniowo-obrzękowe na skórze 


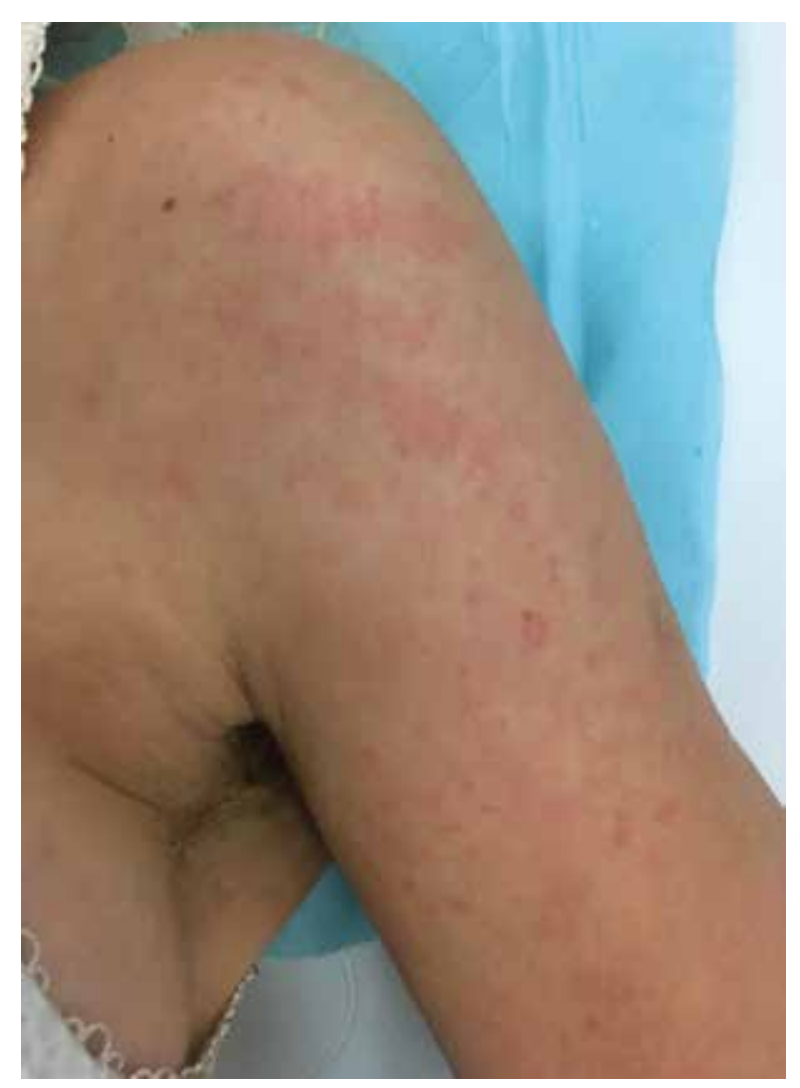

Figure I. Skin lesions on the arm on the day of admission to the Dermatology Department

Rycina I. Zmiany skórne na ramieniu w dniu przyjęcia pacjentki do Kliniki Dermatologii

noon and resolved completely at night, and only rarely occurred in the mornings. Deviations from the reference laboratory values included: erythrocyte sedimentation rate (ESR) $81 \mathrm{~mm}$, leukocytosis $14.9 \mathrm{~K} / \mu \mathrm{l}$, platelets (PLT) $356 \mathrm{~K} / \mu \mathrm{l}$ (normal laboratory range: 150-350 K/ $\mu \mathrm{l}$ ), mean platelet volume (MPV) $9.3 \mathrm{fl}$, neutrophils 13.2 $\mathrm{K} / \mu \mathrm{l}(88.7 \%)$, and C-reactive protein (CRP) $49.1 \mathrm{mg} / 1$. A routinely performed general urine test showed a specific gravity of $1.005 \mathrm{~g} / \mathrm{l}$, and individual squamous epithelial cells and isomorphic erythrocytes (1-3 HPF).

During hospitalization, a skin biopsy was taken from the abdominal integuments for histopathological examination, revealing normotypic epidermis with individual diffused lymphocytes in the dermis. Antinuclear antibodies (ANA) measured by indirect immunofluorescence on the HEp-2 cell line (ANA HEp-2) showed a speckled nuclear immunofluorescence pattern and additionally a cytoplasmic pattern at a titer of $1: 320$. In the immunoblot ANA-profile 23 test, only PML antibodies were weakly positive, while the results of the ANAprofile 5 test (RNP/Sm, Sm, RNP 70, RNP A, RNP C, SSA, Ro-52, SSB, Scl-70, PM, Jo, CB, PCNA, DNA, NUC, HI, RIB, M2) were fully negative (fig. 3).

In view of the morphological appearance of the patient's fingers (figs. 4, 5) capillaroscopy and radio-

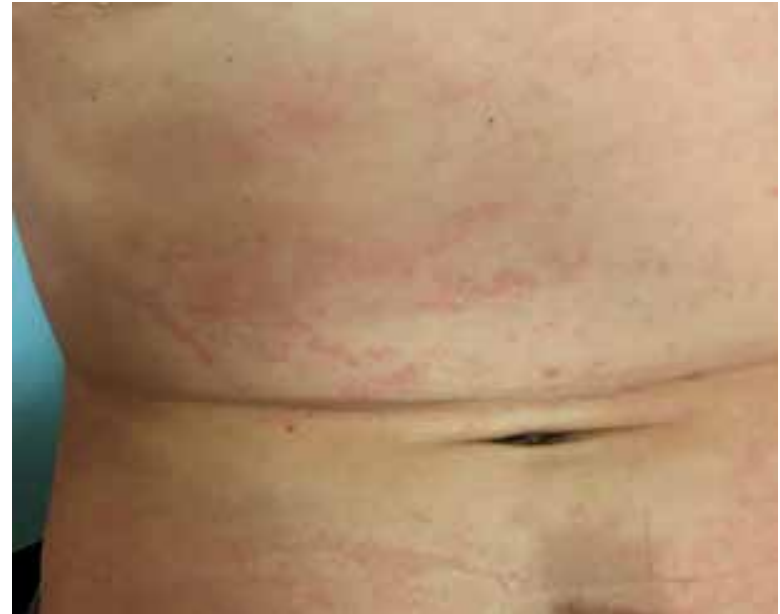

Figure 2. Skin lesions on the trunk on the day of admission to the Dermatology Department

Rycina 2. Zmiany skórne na tułowiu w dniu przyjęcia pacjentki do Kliniki Dermatologii

kończyn górnych, tułowiu oraz udach (ryc. 1, 2). Z wywiadu wynikało, że od roku przed przyjęciem zmiany skórne pojawiały się w godzinach popołudniowych i ustępowały całkowicie w nocy, rzadko występowały w godzinach porannych. W badaniach laboratoryjnych z odchyleń od wartości referencyjnych stwierdzono: odczyn Biernackiego (OB) $81 \mathrm{~mm}$, leukocytozę 14,9 tys./ $\mu$ l, płytki krwi (PLT) 356 tys./ $\mu 1$ (norma laboratoryjna: 150-350 tys./ $\mu \mathrm{l}$ ), średnia objętość płytek krwi (mean platelet volume MPV) 9,3 fl, neutrofile 13,2 tys./ $\mu \mathrm{l}(88,7 \%)$, białko C-reaktywne (C-reactive protein - CRP) 49,1 mg/1. W badaniu ogólnym moczu ciężar właściwy wynosił 1,005 g/1, zaobserwowano pojedyncze nabłonki płaskie oraz świeże erytrocyty (1-3 w polu widzenia).

Podczas hospitalizacji pobrano wycinek skóry z powłok brzusznych do badania histopatologicznego, w którym uwidoczniono prawidłowy naskórek z pojedynczymi rozproszonymi limfocytami w skórze właściwej. W badaniu surowicy metodą immunofluorescencji pośredniej na linii komórkowej HEp-2 stwierdzono obecność przeciwciał przeciwjadrowych (antinuclear antibodies - ANA) w mianie 1 : 320 o jądrowym, plamistym (speckled) i dodatkowo cytoplazmatycznym wzorze świecenia. W badaniu immunoblot profil 23 jedynie przeciwciała PML były słabo dodatnie, a profil 5 (przeciwciała RNP/ Sm, Sm, RNP 70, RNP A, RNP C, SSA, Ro-52, SSB, Scl-70, PM, Jo, CB, PCNA, DNA, NUC, HI, RIB, M2) był całkowicie ujemny (ryc. 3 ).

Ze względu na zmiany morfologiczne palców rąk pacjentki (ryc. 4,5) zalecono kapilaroskopię oraz badanie rentgenograficzne (RTG) obu rąk. W kapilaroskopii wykazano prawidłowy układ naczyń, nie stwierdzono awaskularyzacji, megakapilar, kapilar drzewkowatych i wybroczyn. W RTG wyka- 


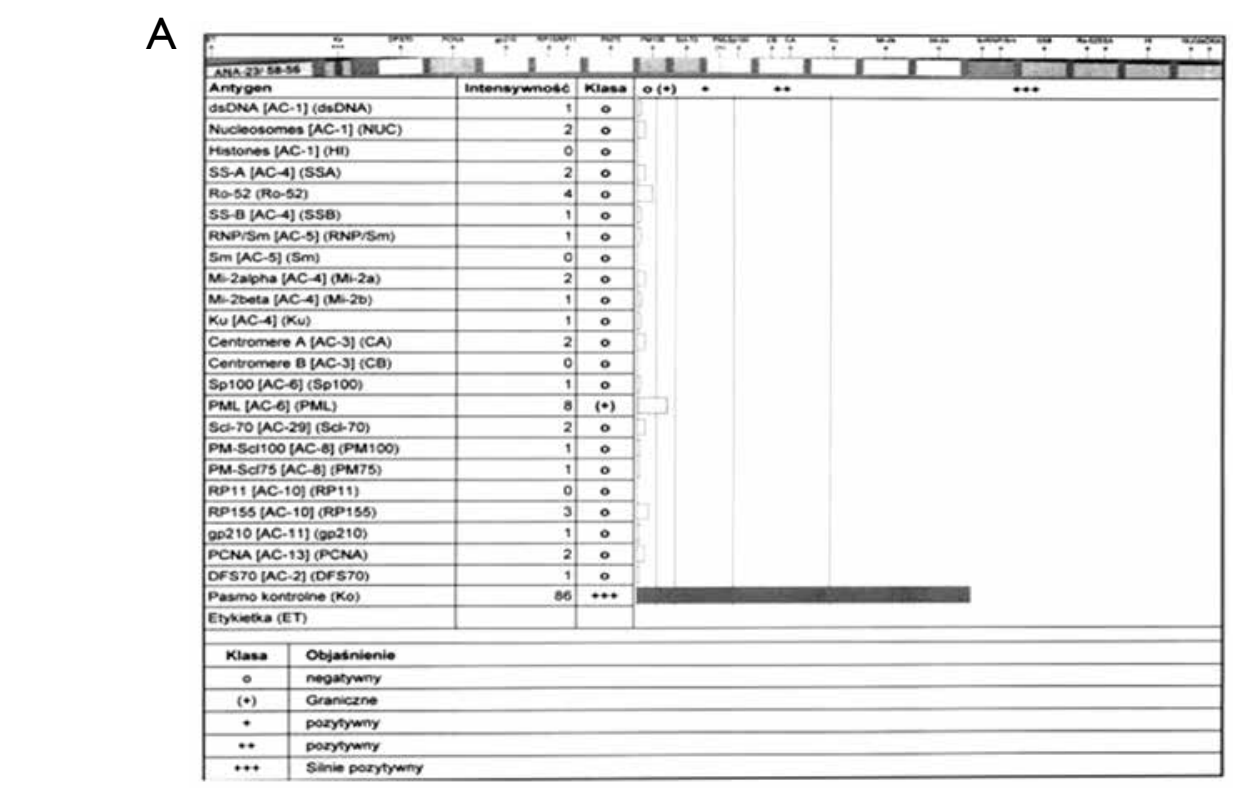

B

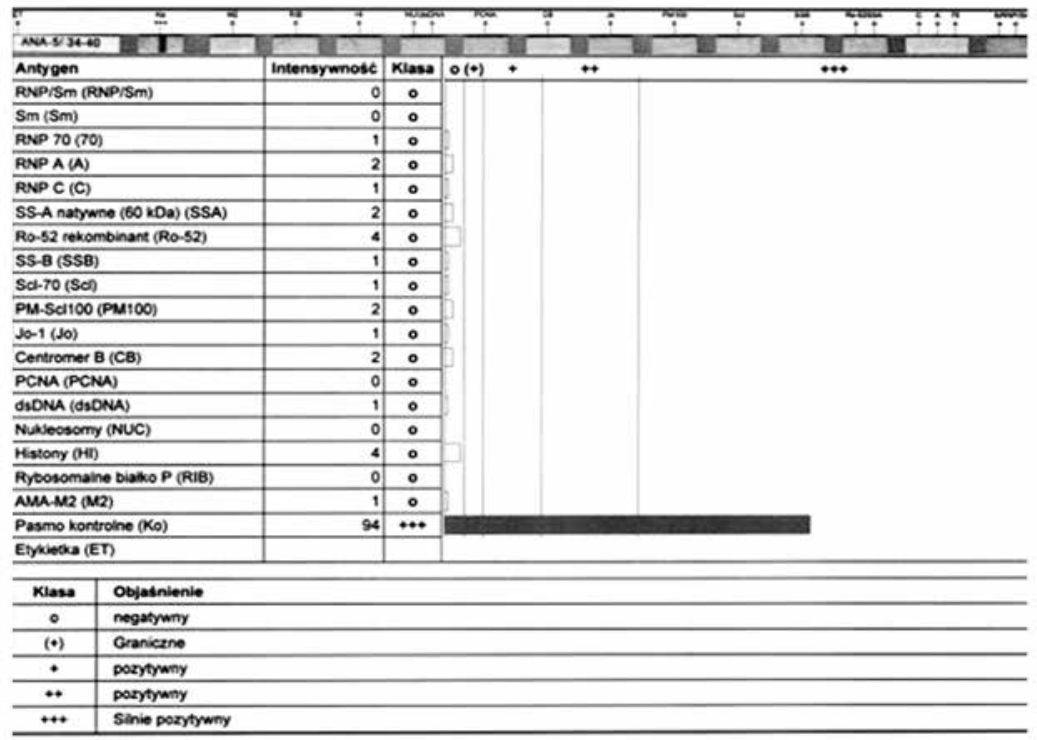
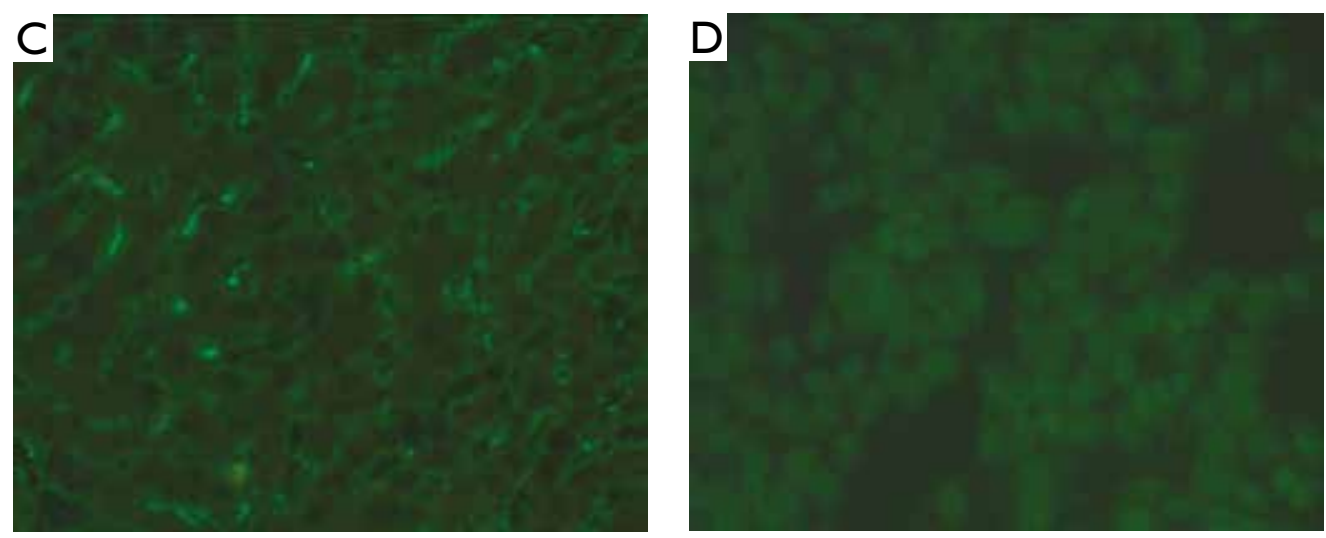

Figure 3. Immunoblot assays: A - profile 23, B - profile 5, and indirect immunofluorescence tests, C - liver cells, D - HEp-2 cells. The entire profile 5 is negative, and in the profile 23 only PML antibodies are weakly positive. Indirect immunofluorescence shows a speckled nuclear pattern and additionally a cytoplasmatic pattern on HEp-2 cells

Rycina 3. Immunoblot: A - profil 23, B - profil 5 oraz obraz immunofluorescencji pośredniej: C - komórki wątroby, D - komórki HEp-2. Profil 5 jest całkowicie ujemny, a w profilu 23 tylko przeciwciała PML są słabo dodatnie. W obrazie immunofluorescencji pośredniej widoczny jest wzór świecenia jądrowy typu plamistego i dodatkowo wzór cytoplazmatyczny na komórkach HEp-2 


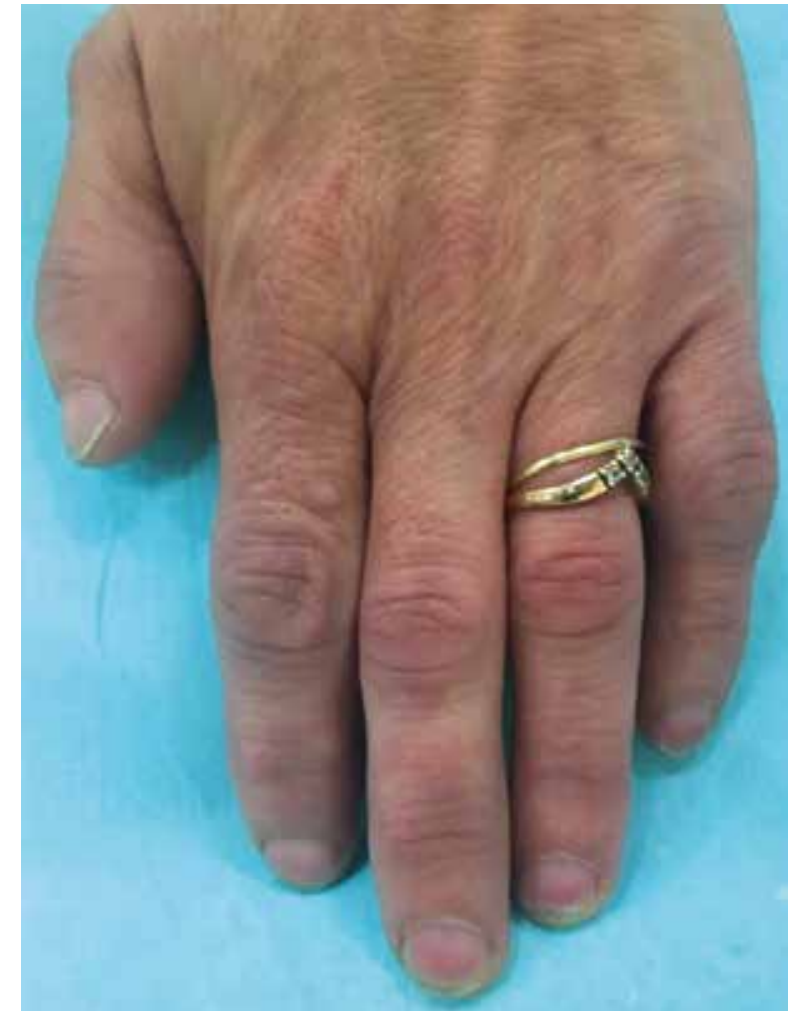

Figure 4. Clinical picture of the dorsal surface of the left hand on the day of admission to the Dermatology Department

Rycina 4. Zmiany skórne na powierzchni grzbietowej ręki lewej w dniu przyjęcia pacjentki do Kliniki Dermatologii

graphic evaluation of both hands were ordered. Capillaroscopy revealed a normal capillaroscopic pattern, without signs of avascularization, megacapillaries, bushy capillaries or petechiae. Radiography found degenerative changes within multiple interphalangeal joints and on the articular margins of the carpal bones.

During hospitalization, no fever or low-grade fever was observed, and after excluding other potential causes of the cutaneous manifestations described above, it was concluded that they were associated with the underlying disease and not due to any additional factors.

In consideration of the fact that the skin lesions appeared every afternoon at about $5 \mathrm{pm}$ and resolved at night, treatment with oral dexamethasone was prescribed, with a dose of $4 \mathrm{mg}$ to be taken one hour before the anticipated development of skin lesions (at $4 \mathrm{pm}$ ). The treatment reduced the frequency of skin lesions secondary to the underlying disease from daily episodes to 2-3 times per week. The patient remains under the care of specialists in the dermatology and rheumatology outpatient clinics.

\section{DISCUSSION}

Cutaneous manifestations develop in approximately $90 \%$ of patients with adult-onset Still's disease [1].

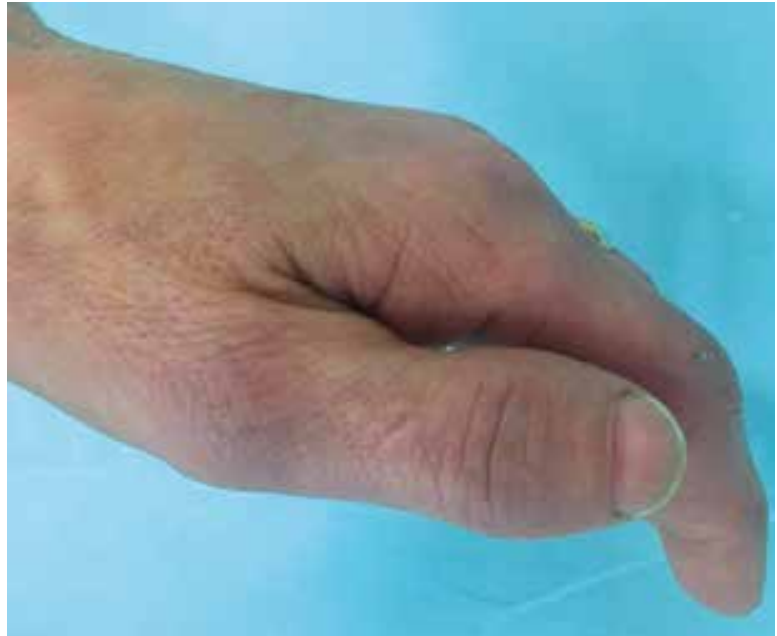

Figure 5. Clinical picture of the medial side of the left hand on the day of admission to the Dermatology Department

Rycina 5. Zmiany skórne na powierzchni przyśrodkowej ręki lewej w dniu przyjęcia pacjentki do Kliniki Dermatologii

zano zmiany zwyrodnieniowe w obrębie licznych stawów międzypaliczkowych oraz na krawędziach stawowych kostek w nadgarstku.

Podczas hospitalizacji nie obserwowano gorączki i stanów podgorączkowych, a po wykluczeniu innych możliwych przyczyn opisanych uprzednio zmian skórnych uznano, że zmiany towarzyszą chorobie podstawowej i nie wynikają z dodatkowych czynników.

W związku z tym, że osutka występowała codziennie około godziny 17.00, a ustępowała w godzinach nocnych, do leczenia włączono doustnie deksametazon w dawce $4 \mathrm{mg}$ /godzinę przed oczekiwanym pojawianiem się zmian skórnych, tj. o godzinie 16.00. Ograniczyło to występowanie zmian skórnych w przebiegu choroby podstawowej z codziennych epizodów do 2-3 na tydzień. Pacjentka nadal jest pod opieką poradni dermatologicznej oraz reumatologicznej.

\section{OMÓWIENIE}

Zmiany skórne występują u około $90 \%$ pacjentów w przebiegu choroby Stilla u dorosłych [1]. Typowa osutka w postaci plam rumieniowych lub zmian rumieniowo-grudkowych o zabarwieniu łososiowym lub łososiowo-różowym pojawia się i ustępuje wraz z gorączką. Zwykle zmiany występują na kończynach i tułowiu, ale mogą pojawić się również na twarzy lub szyi. Rzadko osutce towarzyszy świąd, natomiast może jej towarzyszyć objaw Koebnera [6]. Osutkę można wywołać przez podrażnienie skóry, np. mocne pocieranie ręcznikiem, noszenie nieodpowiedniej odzieży lub ekspozycję na ciepło, np. gorąca kąpiel [1]. 
Table I. Diagnostic criteria of adult-onset Still's disease [I, 3, 5]

Tabela I. Kryteria diagnostyczne choroby Stilla u dorosłych [I, 3, 5]

\begin{tabular}{|c|c|c|}
\hline Major criteria/Kryteria duże & Minor criteria/Kryteria małe & Exclusion criteria/Kryteria wykluczające \\
\hline $\begin{array}{l}\text { Fever } \geq 39^{\circ} \mathrm{C} \text { persisting for more than } \\
\text { I week/Gorączka } \geq 39^{\circ} \mathrm{C} \text { utrzymująca się } \\
\text { powyżej tygodnia }\end{array}$ & Sore throat/Ból gardła & $\begin{array}{c}\text { Infections, especially infectious } \\
\text { mononucleosis and sepsis/Zakażenia, } \\
\text { szczególnie mononukleaza zakaźna i sepsa }\end{array}$ \\
\hline $\begin{array}{l}\text { Arthralgia persisting for more than } \\
2 \text { weeks/Ból stawów trwający powyżej } \\
2 \text { tygodni }\end{array}$ & $\begin{array}{c}\text { Lymphadenopathy and/or splenomegaly/ } \\
\text { Powiększenie węzłów chtonnych i/lub } \\
\text { śledziony }\end{array}$ & $\begin{array}{l}\text { Cancers, especially lymphomas/ } \\
\text { Nowotwory, zwlaszcza chłoniaki }\end{array}$ \\
\hline $\begin{array}{l}\text { Leukocytosis }(\geq|0,000 / \mu|), \text { neutrophils } \\
>80 \% / \text { Leukocytoza }(\geq 10000 / \mu \mid), \\
\text { neutrofile }>80 \%\end{array}$ & $\begin{array}{l}\text { Negative IgM rheumatoid factor (IgM-RF) } \\
\text { and antinuclear antibodies/Ujemne wyniki } \\
\text { czynnika reumatoidalnego RF klasy IgM } \\
\text { i przeciwciał przeciwjądrowych }\end{array}$ & $\begin{array}{l}\text { Other rheumatic diseases, especially } \\
\text { RA-associated vasculitis and polyarteritis } \\
\text { nodosa/Inne choroby reumatyczne, } \\
\text { szczególnie zapalenie naczyń w przebiegu } \\
\text { RZS i guzkowe zapalenie tętnic }\end{array}$ \\
\hline $\begin{array}{l}\text { Characteristic skin rash/ Charakterystyczna } \\
\text { osutka }\end{array}$ & $\begin{array}{c}\text { Elevated serum activity of AST, ALT and } \\
\text { LDH (after excluding other possible } \\
\text { causes)/ Podwyższona aktywność AspAT, } \\
\text { AIAT i LDH w surowicy (po wykluczeniu } \\
\text { innych przyczyn) }\end{array}$ & Infection/Infekcja \\
\hline
\end{tabular}

Table 2. Cutaneous manifestations associated with adult-onset Still's disease: differential diagnosis [9-15]

Tabela 2. Zmiany skórne w przebiegu choroby Stilla u dorosłych - różnicowanie [9-15]

\begin{tabular}{|c|c|}
\hline $\begin{array}{l}\text { Nosological entity/ } \\
\text { Jednostka chorobowa }\end{array}$ & Clinical features of skin lesions/Cechy kliniczne zmian skórnych \\
\hline Urticaria/Pokrzywka & $\begin{array}{l}\text { Monomorphic rash in the form of urticarial wheals, short-term persistence of skin eruptions, resolution } \\
\text { without a trace/Jednopostaciowa osutka w postaci bąbli pokrzywkowych, krótkotrwałe utrzymywanie się } \\
\text { wykwitów, ustępowanie bez pozostawienia śladu }\end{array}$ \\
\hline el & $\begin{array}{l}\text { Erythematous rash resolving without leaving traces, arranged in a symmetrical pattern. Mild general } \\
\text { symptoms accompanying skin eruptions, a tendency to relapse/Osutka rumieniowa o symetrycznym } \\
\text { układzie, ustępująca bez pozostawiania śladów. Nieznaczne objawy ogólne towarzyszące wysiewowi, } \\
\text { skłonność do nawrotów }\end{array}$ \\
\hline $\begin{array}{l}\text { Erythema annulare } \\
\text { centrifugum/Rumień } \\
\text { obrączkowaty } \\
\text { odśrodkowy }\end{array}$ & $\begin{array}{l}\text { Erythematopapular rash spreading peripherally, with a clearing tendency in the central part, forming an } \\
\text { annular pattern. Lower extremities are commonly involved/Osutka rumieniowo-grudkowa szerząca się } \\
\text { obwodowo, część centralna może ulegá́ przejaśnieniu - tworzy pierścieniowaty wzór. Często występuje } \\
\text { na kończynach dolnych }\end{array}$ \\
\hline $\begin{array}{l}\text { Serum sickness/Choroba } \\
\text { posurowicza }\end{array}$ & $\begin{array}{l}\text { Maculoerythematous, papular, urticarial or measles-like rash, often itchy and symmetrically distributed, } \\
\text { initially on the hands, feet and trunk, but the entire body may also be involved/Osutka plamisto- } \\
\text {-rumieniowa, grudkowa, pokrzywkowa lub odropodobna, często swędząca i symetryczna, początkowo } \\
\text { na rękach, stopach i tułowiu, może zajmować całą skórę }\end{array}$ \\
\hline $\begin{array}{l}\text { Exanthema subitum/ } \\
\text { Rumień nagly }\end{array}$ & $\begin{array}{l}\text { Maculopapular rash located mainly on the trunk and neck. Mainly children are affected/Osutka plamisto- } \\
\text {-grudkowa, zlokalizowana przede wszystkim na tułowiu oraz szyi. Występuje głównie u dzieci }\end{array}$ \\
\hline $\begin{array}{l}\text { Syphilis, stage 2/Kiła, } \\
\text { II okres }\end{array}$ & $\begin{array}{l}\text { Macular or (less commonly) papular or papulopustular rash involving the skin and mucous membranes/ } \\
\text { Osutka plamista, rzadziej grudkowa lub grudkowo-krostkowa, zlokalizowana na skórze i błonach } \\
\text { śluzowych }\end{array}$ \\
\hline $\begin{array}{l}\text { Endocarditis/Zapalenie } \\
\text { wsierdzia }\end{array}$ & $\begin{array}{l}\text { Cutaneous and subungual hemorrhages, Osler nodes, Janeway lesions/Wybroczyny skórne } \\
\text { i podpaznokciowe, guzki Oslera, objaw Janewaya }\end{array}$ \\
\hline
\end{tabular}

The typical rash of erythematous macules or erythematopapular lesions, salmon or salmon-pink in color, tends to appear and resolve with fever. In most cases, skin lesions involve the extremities and trunk, but they can also be seen on the face or neck. The skin rash is rarely accompanied by pruritus, but may be associated with the Koebner phenomenon [6]. The rash can be triggered by skin irritation, for example by rubbing it vigorously with a towel or wearing improper clothing, or by heat, such as when taking a hot bath [1].
W piśmiennictwie można znaleźć opisy różnych morfologicznie zmian w przebiegu AOSD, między innymi zmian rumieniowych, zmian linijnych $\mathrm{z}$ towarzyszącym świądem, grudek na podłożu rumieniowym, które mogą być pokryte łuskami, zmian pokrzywkowych, pokrzywkopodobnych, osutki pęcherzykowo-krostkowej przypominającej zmiany trądzikopodobne lub trwałych przebarwień [2, 6-8]. Do chorób dermatologicznych, które mogą towarzyszyć chorobie Stilla u dorosłych, zalicza się: obrzęk naczynioruchowy, zespół Sweeta, łysienie oraz guz- 
In the literature, there are reports of a variety of cutaneous manifestations associated with the disease, including erythematous lesions, linear changes accompanied by pruritus, rash consisting of papules on an erythematous base (with or without scaling), urticarial rash or urticaria-like skin lesions, vesiculopustular lesions resembling acne-like rash, and permanent skin discoloration [2, 6-8]. Dermatological conditions which may accompany adult-onset Still's disease include angioedema, Sweet's syndrome, alopecia, and polyarteritis nodosa [7]. However, it is not apparent from the literature review whether comorbidities are linked to Still's disease.

To diagnose Still's disease, defined clinical and laboratory criteria must be met, i.e. at least 5 of the major and minor criteria including at least 2 major criteria, with no disorders listed under exclusion criteria $[1,5]$ (table 1).

The treatment of AOSD is based on non-steroidal anti-inflammatory drugs (NSAIDs) to reduce fever and relieve pain. If no satisfactory therapeutic response is noted, systemic glucocorticosteroids, typically oral prednisone, are introduced at a dose of $0.5-1.0 \mathrm{mg} / \mathrm{kg}$ $\mathrm{BW} /$ day. An alternative treatment option is intravenous methylprednisolone at a dose of $1,000 \mathrm{mg} /$ day for 3 days. Chronic treatment in patients with symptoms of polyarthritis is based on methotrexate. In refractory cases, biological treatment with inhibitors of tumor necrosis factor or interleukin 6 is used. Initiating appropriate physical rehabilitation is recommended in parallel with pharmacological treatment in order to reduce the risk of bone fusions $[1,3,5]$.

\section{CONCLUSIONS}

Adult-onset Still's disease is a rare nosological entity. The diagnosis can be challenging because a similar skin rash may occur in a number of diseases. Still's disease should be considered in the differential diagnosis in patients presenting with a salmon-colored macular or maculopapular skin rash and a history of intermittent low-grade fever and joint pain (table 2). It is also important to note that skin lesions in AOSD may be atypical. For example, they may be unrelated to fever (as in our patient), or present as urticarial lesions or acne-like rash. A correct diagnosis is very important in order to initiate appropriate treatment preventing destructive joint damage.

\section{CONFLICT OF INTEREST}

The authors declare no conflict of interest. kowe zapalenie tętnic [7]. Z piśmiennictwa nie można jednak wywnioskować, czy choroby współistniejące mają związek z chorobą Stilla.

Do rozpoznania choroby Stilla konieczne jest spełnienie określonych kryteriów klinicznych i laboratoryjnych, tj. co najmniej 5 kryteriów spośród kryteriów dużych i małych, w tym co najmniej 2 kryteria duże, a ponadto nie może wystąpić żaden stan chorobowy spośród wymienionych w kryteriach wykluczających $[1,5]$ (tab. 1).

W leczeniu AOSD stosuje się niesteroidowe leki przeciwzapalne (NLPZ) w celu obniżenia gorączki i zmniejszenia dolegliwości bólowych. W przypadku braku zadowalających efektów włącza się glikokortykosteroidy ogólne, zwykle prednizon doustnie w dawce 0,5-1,0 mg/kg m.c./dobę lub metyloprednizolon dożylnie w dawce 1000 mg/dobę przez 3 dni. Przy objawach zapalenia wielostawowego w terapii przewlekłej stosuje się metotreksat, a w opornych przypadkach leczenie biologiczne - inhibitory TNF lub inhibitor interleukiny 6 . Jednocześnie z leczeniem farmakologicznym zaleca się rozpocząć odpowiednią rehabilitację, która ma na celu zmniejszenie ryzyka wystąpienia zrostów kostnych $[1,3,5]$.

\section{WNIOSKI}

Choroba Stilla u dorosłych jest rzadką jednostką chorobową. Jej rozpoznanie może stanowić trudność, gdyż podobna osutka występuje w wielu innych schorzeniach. U pacjenta z osutką plamistą lub plamisto-grudkową o łososiowym zabarwieniu, który w wywiadzie podaje okresowe stany podgorączkowe i dolegliwości bólowe stawów, w różnicowaniu należy uwzględnić chorobę Stilla (tab. 2). Należy także pamiętać, że zmiany skórne w AOSD mogą przebiegać nietypowo, np. bez związku z gorączką, podobnie jak u opisanej pacjentki, jak również w postaci zmian pokrzywkowych lub osutki trądzikopodobnej. Istotne jest właściwe rozpoznanie, aby wdrożyć skuteczne leczenie, co zapobiega destrukcyjnym zmianom stawowym.

\section{KONFLIKT INTERESÓW}

Autorzy nie zgłaszają konfliktów interesów. 


\section{References}

\section{Piśmiennictwo}

1. Zimmermann-Górska I.: Reumatologia kliniczna. [In:] Choroba Stilla u dorosłych. Zimmermann-Górska I. (ed.), Wydawnictwo Lekarskie PZWL, Warszawa, 2008, 541-547.

2. Nataraja C., Griffiths H.: Atypical cutaneous manifestations in adult onset Still's disease. Case Rep Rheumatol 2016, 2016, 4835147.

3. Leszczyński P., Pawlak-Buś K., Szafrański T.: Choroba Stilla u dorosłych jako przyczyna gorączki o niejasnej etiologii. Postep Wiedzy Med 2012, 2, 120-127.

4. Gerfaud-Valentin M., Jamilloux Y., Iwazs J., Sève P.: Adult-onset Still's disease. Autoimmun Rev 2014, 13, 708-722.

5. Zimmermann-Górska I.: Choroba Stilla u dorosłych. Medycyna praktyczna dla lekarzy 2018.

6. Yamamoto T.: Cutaneous manifestations associated with adult-onset Still's disease: important diagnostic values. Rheumatol Int 2012, 32, 2233-2237.

7. Turkyilmaz A., Devrimsel G., Topaloglu M., Erturk A., Capkin A.A., Yildirim M.: Atypical skin rash in a patient with adult-onset Still's disease: a case report. Oman Med J 2013, 28, e052.

8. Garcia F.J.N., Pascual M., López de Recalde M., Juarez P., Morales-Ivorra I., Notario J., et al.: Adult-onset Still's disease with atypical cutaneous manifestations. Medicine (Baltimore) 2017, 96, e6318.

9. Gomes R., Tiberto L., Monte Bello V., Lima M., Nai G., Morgado de Abreu M.: Dermatologic manifestations of infective endocarditis. An Bras Dermatol 2016, 91, 92-94.

10. Seo H.J., Lee J.: Serum sickness reaction with skin involvement induced by bee venom injection therapy. Asia Pac Allergy 2015, 5, 230-233.

11. Mandel V.D., Ferrari B., Manfredini M., Giusti F., Pellacani G.: Annually recurring erythema annulare centrifugum: a case report. J Med Case Rep 2015, 9, 236.

12. Stoeckle M.Y.: The spectrum of human herpesvirus 6 infection: from roseola infantum to adult disease. Annu Rev Med 2000, $51,423-430$.

13. Radonjic-Hoesli S., Hofmeier K.S., Micaletto S., Schmid-Grendelmeier P., Bircher A., Simon D.: Urticaria and angioedema: an update on classification and pathogenesis. Clin Rev Allergy Immunol 2018, 54, 88-101.

14. Sokumbi O., Wetter DA.: Clinical features, diagnosis, and treatment of erythema multiforme: a review for the practicing dermatologist. Int J Dermatol 2012, 51, 889-902.

15. Wojas-Pelc A., Pastuszczak M., Serwin A.B., Rudnicka I., Majewski S., Czajkowski R., et al.: Kiła. Rekomendacje diagnostyczno-terapeutyczne Polskiego Towarzystwa Dermatologicznego. Część I: kiła wczesna i późna. Dermatol Rev 2018, 105, 563-581.

Received: 9.06 .2020

Accepted: 26.10 .2020

Otrzymano: $9.06 .2020 \mathrm{r}$.

Zaakceptowano: $26.10 .2020 \mathrm{r}$. 